Required software to e-Annotate PDFs: Adobe Acrobat Professional or Adobe Reader (version 11 or above). (Note that this document uses screenshots from Adobe Reader DC.)

The latest version of Acrobat Reader can be downloaded for free at: http://get.adobe.com/readerl

Once you have Acrobat Reader open on your computer, click on the Comment tab (right-hand panel or under the Tools menu).

This will open up a ribbon panel at the top of the document. Using a tool will place a comment in the right-hand panel. The tools you will use for annotating your proof are shown below:

\begin{tabular}{|c|c|}
\hline [A Export PDF & $\checkmark$ \\
\hline 든 Create PDF & $\checkmark$ \\
\hline 吕 Edit PDF & $\checkmark$ \\
\hline
\end{tabular}

Comment

1. Replace (Ins) Tool - for replacing text. box where replacement text can be entered.

How to use it:

- Highlight a word or sentence.

- Click on $\frac{T}{1}$.

- Type the replacement text into the blue box that appears.

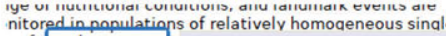
$n$ of saceharemyees , and Is initrated alter jstaddon Reply $\mathrm{X}$

; carbon source [ $[1]$.

are referred to as mei.

$n$ of meiosis-specific $\subseteq$

revisiae depends on th

inducer of meiosis) [3

repression, the genes

rase II mediator subur

osome density [8]. Si

irectly or indirectly re
T. Strikes a line through text and opens up a text

1 functions as a repre

2. Strikethrough (Del) Tool - for deleting text.

T. Strikes a red line through text that is to be $\mp$ deleted.

How to use it:

- Highlight a word or sentence.

- Click on $\frac{T}{\perp}$.

- The text will be struck out in red.

experımental data It avallable. ror URrs to be had to meet all of the following criteria:

1. Small size (35-250 amino acids).

2. Absence of similarity to known proteins.

3. Absence of functional data which could n the real overlapping gene.

4. Greater than $25 \%$ overlap at the N-termir terminus with another coding feature; ov $\epsilon$ both ends; or ORF containing a tRNA.

4. Insert Tool - for inserting missing text at specific points in the text.

to be changed to bold or italic or for genera comments.

P Use these 2 tools to highlight the text where a comment is then made.

How to use it:

- Click on .

- Click and drag over the text you need to highlight for the comment you will add.

- Click on $\ominus$.

- Click close to the text you just highlighted.

- Type any instructions regarding the text to be altered into the box that appears.

nformal invariance: $r$ A: Math. Gen., Vol. 12, ^ This needs to be bold

lified theory for a matri

'ol. 8, 1984, pp. 305-323

:d manuscript, 1984.

shing fractions for $\mathrm{DO} \rightarrow \mathrm{K}+\mathrm{K}$

olation in nn derave' Dhve
T Marks an insertion point in the text and opens up a text box where comments can be entered.

How to use it:

- Click on $\mathrm{T}_{\boldsymbol{Q}}$

- Click at the point in the proof where the comment should be inserted

- Type the comment into the box that appears.

Meiosis has a central role in the sexual reproduction of nearly all eukaryotes foccharom. analysis of meiosis, esp jstaddon Reply $\times$, trigs $\begin{array}{lll} & \text { its a } \\ \text { conveniently monitored } & \text { Yeast, } & \text { is sin }\end{array}$ cells. Sporulation of Sat ne ty

cell, the a/ $\alpha$ cell, and is

sporulation and are refe

2b]. Transcription of me

activator, IMEI (inducer
of the gene RMEI funct
Rmelp to exert repressi

Rmelp to exert repressi
of GAL1 gene expression, and $K G K 1$ are required $[1,2,3,1]$. Inese $g 6$ of a fermentable carbor

meiosis, in S. cerevisiae
activator, IMEI (induce, 
5. Attach File Tool - for inserting large amounts of text or replacement figures.

2. Inserts an icon linking to the attached file in the 母. appropriate place in the text.

How to use it:

- Click on $\&$.

- Click on the proof to where you'd like the attached file to be linked.

- Select the file to be attached from your computer or network.

- Select the colour and type of icon that will appear in the proof. Click OK.

The attachment appears in the right-hand panel.

shondrial preparatior ative datuage injury

ie extent of membra I, malondialdehyde ( (TBARS) formation. ' mad bu biak narfam
6. Add stamp Tool - for approving a proof if no corrections are required.

$\Omega$. Inserts a selected stamp onto an appropriate 든 in the proof.

How to use it:

- Click on $\Omega$.

- Select the stamp you want to use. (The Approved stamp is usually available directly in the menu that appears. Others are shown under Dynamic, Sign Here, Standard Business).

- Fill in any details and then click on the proof where you'd like the stamp to appear. (Where a proof is to be approved as it is, this would normally be on the first page).

tr the business cycie, starung with the on perfect competition, constant ret

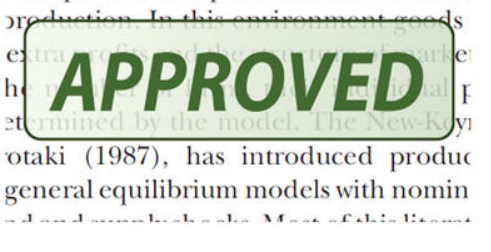

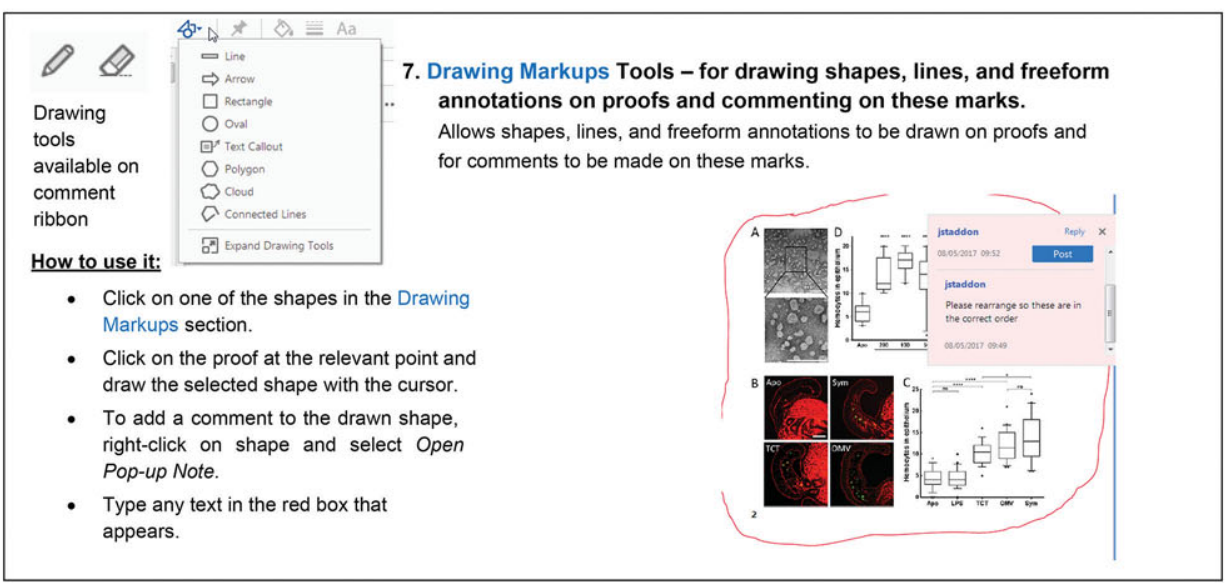

For further information on how to annotate proofs, click on the Help menu to reveal a list of further options:

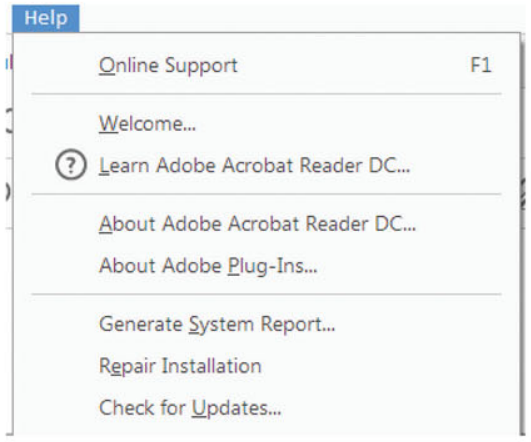




\title{
Three-dimensional geophysical characterization of the La Rambla and Zafra de Záncara anticlines (Loranca Basin, Central Spain)
}

\author{
C. Ayala ${ }^{1 *, \dagger}$, F.M. Rubio ${ }^{1}$, C. Rey-Moral ${ }^{1}$, M.I. Reguera ${ }^{2}$ and C. Biete ${ }^{3}$ \\ ${ }^{1}$ IGME (Spanish Geological Survey), La Calera n. 1, 28760 Tres Cantos, Madrid, Spain, ${ }^{2}$ IGME (Spanish Geological Survey), Rios Rosas n. \\ 23, 28003 Madrid, Spain, and ${ }^{3}$ Institute of Earth Sciences Jaume Almera, ICTJA, CSIC, Lluis Sole i Sabaris s/n, 08028 Barcelona, Spain
}

Received January 2018, revision accepted January 2019

\begin{abstract}
The Zafra de Záncara anticline (also known as the El Hito anticline), located in the Loranca Cenozoic Basin (part of the Tagus Basin, Central Spain), had been studied by several oil companies during the late 1960s and early 1970s. In 2009, within the 'Plan for selection and characterization of suitable structures of $\mathrm{CO}_{2}$ geological storage', this anticline was selected as a potential $\mathrm{CO}_{2}$ storage site. A preliminary three-dimensional geological model, based on five geological cross sections that were constrained with the interpretation of the available seismic profiles (that are rather old and do not have very good quality), was created. With the aim of improving the geological knowledge of the Zafra de Záncara anticline and helping to investigate the suitability of a nearby anticline, namely La Rambla, as another structural closure that might make it a possible $\mathrm{CO}_{2}$ storage site, a local gravity survey (ene-station every square kilometres) was carried out in the area, seven new geological cross sections, based on these existing seismic profiles and field geology, were build, and a new three-dimensional geological model that included both anticlines, improved through three-dimensional stochastic gravity inversion, was constructed. The densities needed for the geological formations of the model come from the analysis of rock samples, logging data from El Hito-1 drillhole and petrophysical information from Instituto Geológico y Minero de España database. The inversion has improved the knowledge about the geometry of the anticlines' traps and seals as well as the geometry of the basement relief and the structural relationship between basement and cover.
\end{abstract}

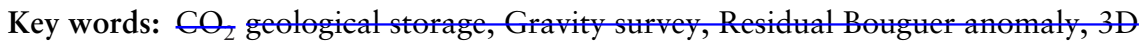
gravity inversion, Loranea Basin, Zafra de Zánara, La Rambla,

\section{INTRODUCTION}

The mitigation of the greenhouse gas emissions, in particular $\mathrm{CO}_{2}$, is being one of the main concerns in order to fight against the climate change. Since 2009, the Spanish Geological Survey has been developing a long term project called 'Plan for selection and characterization of suitable structures

*E-mail: c.ayala@igme.es

${ }^{\dagger}$ Now visiting at the Institute of Earth Sciences Jaume Almera, ICTJA, CSIC, Lluis Solé i Sabarís s/n, 08028 Barcelona, Spain of $\mathrm{CO}_{2}$ geological storage' (IGME, 2009). The first stage of this plan has been evaluating and pre-selecting a number of possible favourable areas at a regional level whose local structures might have structural closures that make them suitable as $\mathrm{CO}_{2}$ storage sites because its adequate geological features, good storage capacity based on preliminary calculations and the reasonable cost of developing the corresponding infrastructures.

The methodology followed to select those favourable areas can be summarized as follows: 
1. compilation and analysis of the available existing geological and geophysical information (from IGME databases and available information from the literature);

2. constructing regional geological cross sections based on the compiled data, which include reinterpreted old seismic lines (that had to be converted into digital format) and deep drillholes;

3. building up isolines and isopachs of the main reference surfaces (top of the basement, Buntsandstein-Mushelkalk, Keuper, Lower Jurassic, Upper Jurassic, Cretaceous and Cenozoic), based on geological cross sections and geophysical information. In different areas, these reference surfaces have different degrees of resolution, depending on the geological and geophysical data available. In some cases, like in the Zafra de Záncara anticline, only some of the isolines (top of the Basement, Buntsandstein-Mushelkalk, Keuper) were considered and therefore, drawn;

4. identification of the possible formation pairs storage/seal according to lithology, thickness, depth and geometry;

5. petrophysical characterization of the storage and seal formations;

6. preliminary estimation of the $\mathrm{CO}_{2}$ storage capacity of the selected structures.

The second stage of this plan consists of completing more detailed studies of the selected structures in order to obtain a more precise image of the structural closures that might be used as reservoir. This image could be used to calculate more accurately its storage capacity. The present work focuses on refining one of these selected structures, Zafra de Záncara anticline, and characterizes a new possible structure, namely the La Rambla anticline that was not taken into account in the first stage but we believe it is worth considering as possible storage site by analogy with its neighbouring anticline.

In these structures, two possible pairs of storage/seal formations were identified: Buntsandstein sandstones and Muschelkalk limestones as a structural closure with Keuper evaporites and shales as a seal; fractured limestones of Lower Jurassic as a structural closure with Jurassic marls as a seal. This two anticlines have been targeted because they show a rather simple tectonic structure, they are located in a suitable socioeconomic and a stable geodynamic contexts and the possible pairs storage/seal formations seem to have an adequate geometry and thickness.

In this study area, the seismic lines, some of which were already used in the first stage, are more than 40 years old with a lot of noise and poor reflectivity, which makes difficult their accurate interpretation. In addition, there is only one logged borehole in the area that could help to interpret the seismic data, El Hito-1. Therefore, with the objective of improving the knowledge of the Zafra de Záncara anticline and characterize the La Rambla anticline in order to assess their suitability as storage site we have chosen to apply the gravity method, a cost-efficient way to study the density distribution and the geometry of the target structures. Thus, three gravimetric surveys were carried out between the end of 2009 and the beginning of 2012 acquiring a total of 577 stations. The surveys included the collection of some rock samples to obtain density values in order to constrain the density of the model. The available geological and geophysical data were used to build a preliminary three-dimensional (3D) model. Furthermore, the gravity data were processed and analysed to obtain the residual Bouguer anomaly in order to improve the preliminary $3 \mathrm{D}$ model through gravity inversion to obtain a final model, consistent with all the available geological and geophysical data.

In this way, it has been possible to refine the $3 \mathrm{D}$ architecture of the different lithological horizons and the depthdensity distribution of the structures providing more insights into its structural pattern and its significance in terms of possible structural closures that might be used as $\mathrm{CO}_{2}$ reservoirs.

\section{GEOLOGICAL SETTING}

The Tagus Basin is an intraplate basin limited to the N-NW by the Spanish Central System, to the NE by the Iberian Chain and to the SW by the Toledo Mountains. This basin is, in turn, divided into two sub-basins separated by the Altomira Range, Madrid Basin and Loranca Basin (also known as Intermediate Depression) (Fig. 1). The Madrid Basin is an intracratonic basin located in the central and western part of the Tagus Basin and filled by Cenozoic sediments overlying the Mesozoic and Paleozoic basement. The Loranca Basin, located in the easternmost part, is a piggyback basin containing approximately N-S striking, mostly west-vergent thrustrelated folds formed during Late Oligocene-Early Miocene time (Díaz Molina et al. 1995). Although most Loranca structures do not crop out, they are identifiable in seismic profiles (Querol 1989; ITGE 1990) and affect a Mesozoic-Cenozoic cover detached over a regional décollement level formed by Middle-Upper Triassic evaporites and clays (e.g. Gómez, Díaz Molina and Lendínez 1996; Muñoz-Martín \& De Vicente 1998).

In this tectonic environment, the study area (Fig. 1) is located in the southern part of the Loranca Basin, between the Altomira Range and the SW part of the Iberian Range. Its extension is about $1200 \mathrm{~km}^{2}$ covering four 


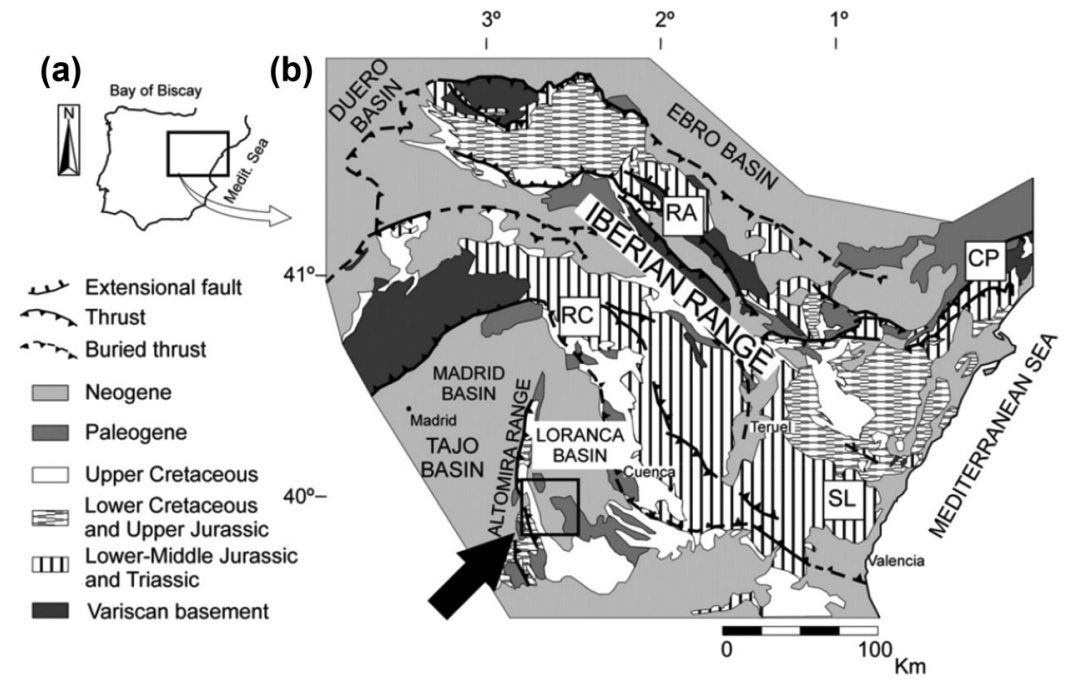

Figure 1 Location map of the study area, modified from Piña-Varas et al. (2013). CP, Catalan pre-litoral Coastal Range; RA, Aragonese branch of the Iberian Range; RC, Castilian branch of the Iberian Range; SL, Levante sector of the Iberian Range.

MAGNA geological maps 1:50,000 scale (http://mapas.igme. es/Servicios/default.aspx\#IGME_MAGNA_50). In the area (Fig. 2), there are a series of anticlines with a general direction N-NW to S-SE. These anticlines have lengths between 5 and $20 \mathrm{~km}$ and width of approximately $3-4 \mathrm{~km}$ being the most relevant Zafra de Záncara anticline, also known as the El Hito anticline (which is the longest one) and La Rambla anticline. According to Querol (1989), these anticlines mainly affect the Mesozoic rocks, from the Upper Triassic to the Upper Cretaceous and also part of the Cenozoic infill, mainly Paleogene. The level of detachment is located in the evaporitic materials of the Keuper facies (evaporites and shales) (Álvaro, Capote, Vegas 1979; Guimerá and Álvaro, 1990). Below this sedimentary cover, the interpretation of the available seismic data (from the seventies) suggest that the Paleozoic and Lower Triassic basement is deformed by a series of horsts and grabens that are related to basement anticlines (the N-S structures) and extensive faults (e.g. Valcárcel-Rodriguez, 2015).

\section{Previous geological interpretation}

In the model published in the ALGECO2 Atlas (IGME 2009), within the area of La Rambla-Zafra de Záncara Complex, the map of basement isolines (Fig. 3a) reveals a tectonics of blocks limited by faults that, according to the seismic data, do not affect the post-Triassic cover. According to previous studies (IGME 2009), these are normal faults generated during the first stage of Triassic rifting that later were inverted. Two basement structural highs associated with the Zafra de Záncara anticline can be observed. These structures could have closure perimeters around $-1600 \mathrm{~m}$ and $-2200 \mathrm{~m}$, respectively (datum: sea level) (Fig. $3 \mathrm{~b}$ ). In the area of the La
Rambla anticline the basement shows a much lower relief, and it has not been possible to delimit structural closures in it, neither to the south, nor to the west due to lack of information (the available seismic data was scarce and not always of good quality). Thickness of the Buntsandstein-Muschelkalk (see the geometry of the top of this layer in Fig. 3b) varies between 200 and $400 \mathrm{~m}$; that of the Keuper changes from tens of meters to more than $1000 \mathrm{~m}$ beneath some areas (Fig. 3c). Thicknesses of the remaining layers come from the geological cross sections (Fig. 4): Jurassic has a thickness of c. $1000 \mathrm{~m}$, and Cretaceous is between 250 and $500 \mathrm{~m}$ thick. As for the Cenozoic, its thickness varies from a few tens of meters to more than $500 \mathrm{~m}$ in some places.

\section{GRAVITY SURVEY}

New 577 gravity stations were measured with an homogeneous distribution of approximately 1 point $/ \mathrm{km}^{2}$ (Fig. 2) using a Scintrex CG5 gravity meter with a standard resolution of 1 microGal and a nominal repeatability of less than 5 microGal. The Scintrex CG5 applies the luni-solar correction, and the measurements were performed in cycles of 4-6 $\mathrm{h}$, and then corrected for instrumental drift. The near topographic correction (Hammer sectors B to D up to $170 \mathrm{~m}$ ) was performed on the field. The survey was linked with the IGSN71 network (International Gravity Standarization Network) in order to obtain the values of the observed gravity (gobs). Post-processing differential GPS has been used to determine the spatial coordinates in UTM30N and the elevation in orthometric heights. To ensure the quality of the data, and following the directions from the UNE Norm 22-611-85 (Instituto Español de Normalización, 1985), 7\% of the stations have 


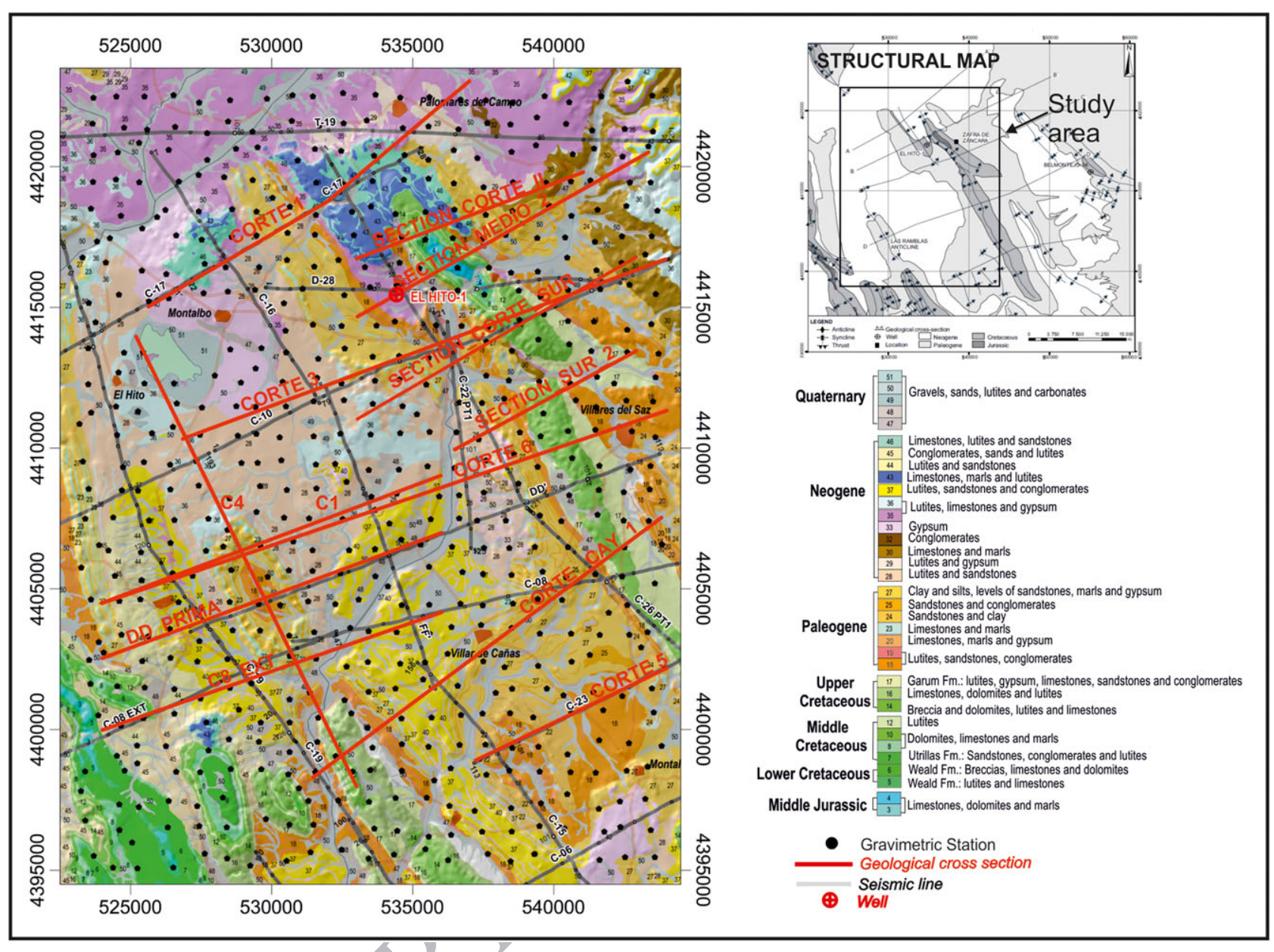

Figure 2 Geological map of the study area. Grey linés: old seismic data; red lines: cross sections based on reinterpreted seismic data and/or surface geology that have been incorporated in the modelling; black dots: spatial distribution of the newly acquired gravity stations. The location of El Hito-1 drillhole is also shown.

been repeated. The root mean square (RMS) of the repetitions is calculated as

$$
\mathrm{RMS}= \pm \sqrt{\frac{\Sigma d^{2}}{2 N}},
$$

where $d$ is the difference between the first measure and the repeated measure and $\mathrm{N}$ the number or repeated points. The RMS of the repetitions is displayed on Table 1.

\section{Bouguer anomaly: Regional-residual separation}

The observed gravity was corrected for the latitude, free air and Bouguer plate, and then the topographic correction was applied to obtain the complete Bouguer anomaly. The gravity data has been processed with the GRS67 (Geodetic Reference
System) formulas so the new gravity data will be compatible with the one stored in the IGME database.

We used the Bouguer correction density, i.e. reduction density, of $2.3 \mathrm{~g} / \mathrm{cm} 3$ determined by the Nettleton method (Nettleton, 1971), which is based on calculation of the Bouguer anomaly with different reduction densities and selection of the density value providing the lowest correlation between the Bouguer anomaly and topography. The topographic correction was calculated using the Hammer method (Hammer, 1939) up to 21,943 m and a Digital Terrain Model grid with $100 \mathrm{~m}$ spacing.

The complete Bouguer anomaly (Bouguer anomaly from now on, Fig. $5 \mathrm{a}$ ) was gridded at $500 \mathrm{~m}$. The homogeneous distribution of the point data allows preserving the short wavelength component without introducing spurious anomalies. 

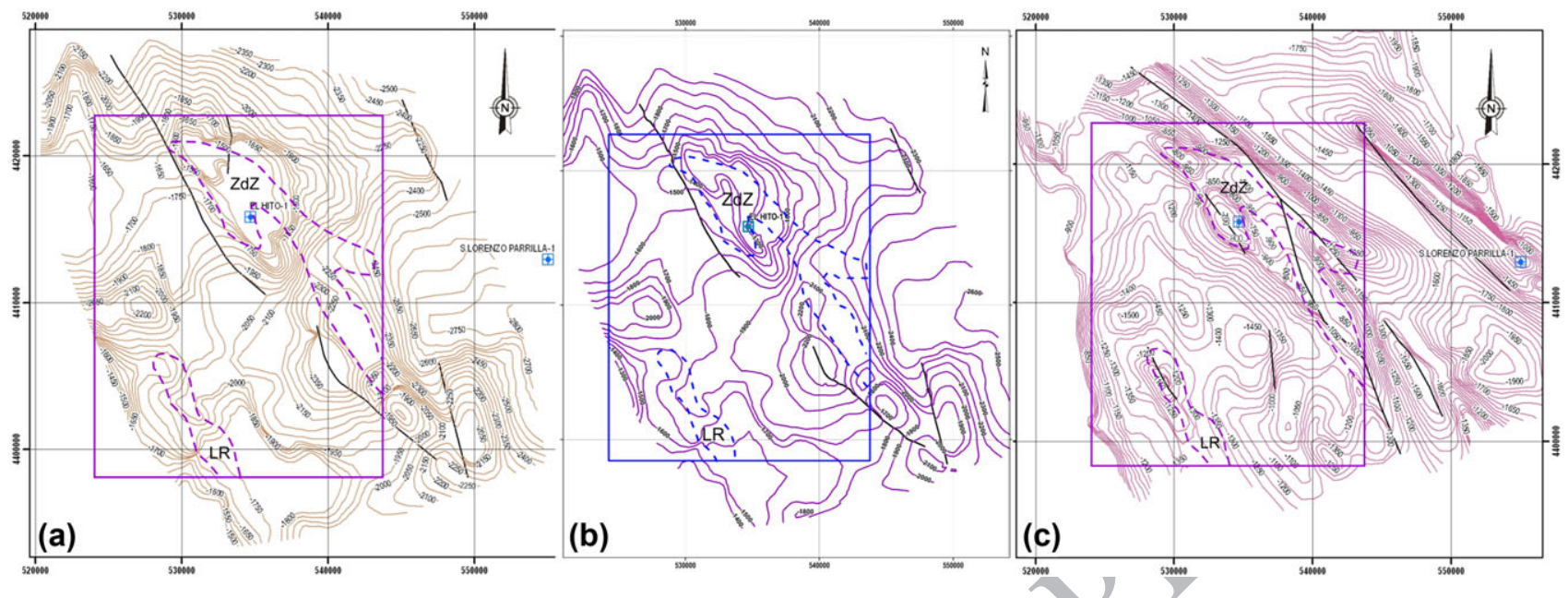

Figure 3 Isolines of the top of formations published in the ALGECO2 Atlas (IGME, 2009). Black lines are interpreted basement faults. In each figure, a rectangle shows the study area of the present work, and discontinuous lines delimit the outline of the geological outcrops of the La Rambla (LR) and Zafra de Záncara (ZdZ) anticlines. The El Hito-1 borehole is also shown in Fig. 3(a, c) (the displayed S. Lorenzo Parrilla-1 borehole is part of the Atlas map but is outside our study area and, therefore, not mentioned on the text).All depths are in $\mathrm{m} \mathrm{b}$. s. l. (a) Top of the basement. (b) Top of Buntsandstein-Muschelkalk. (c) Top of Keuper.

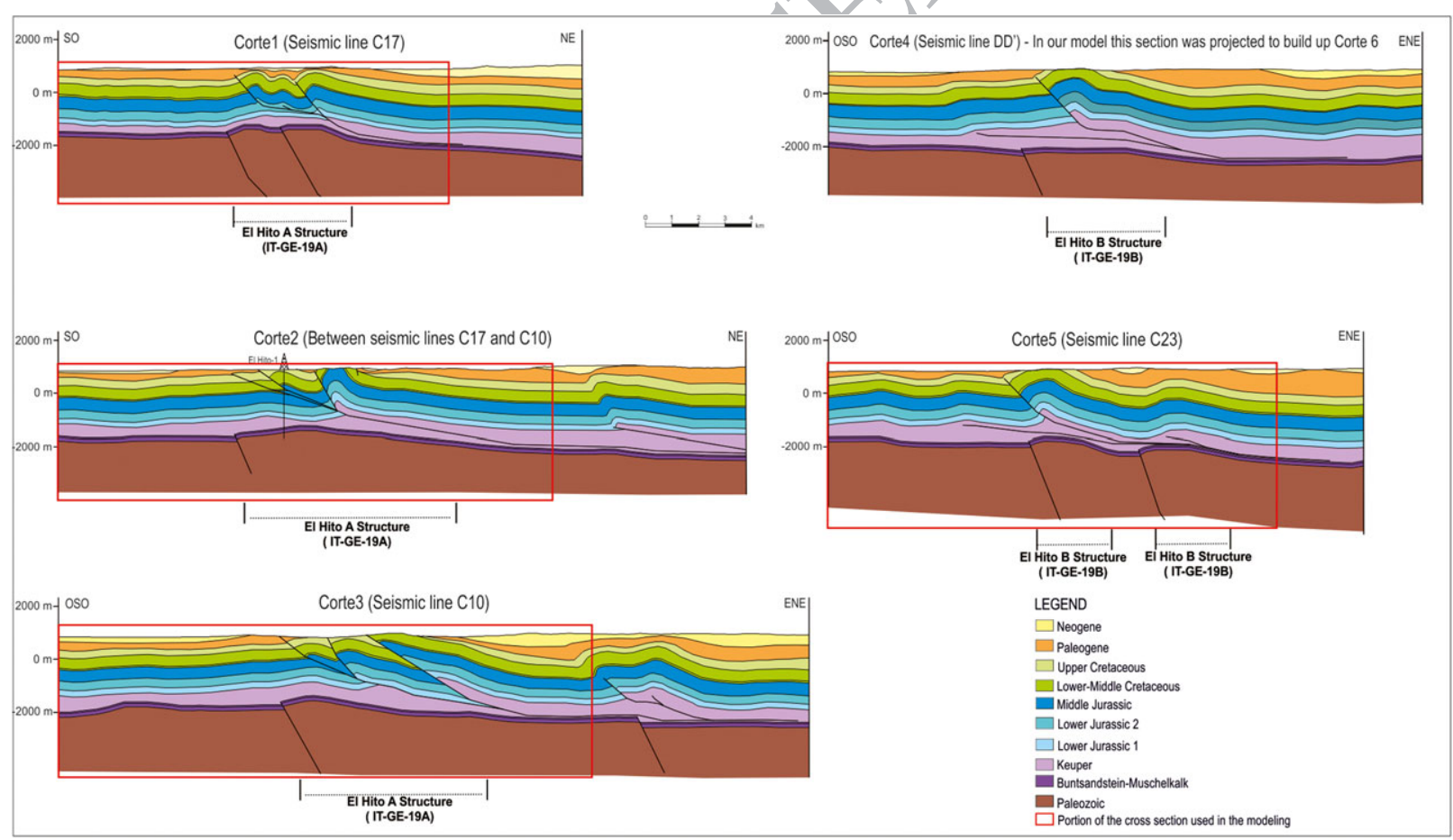

Figure 4 Cross sections from ALGECO2 Atlas (IGME, 2009). Part of these cross-sections where integrated in the initial geological model. The portion of each cross section used in the modelling is outlined with a red rectangle. Note that Corte 4 (interpreted from the eastern part of seismic line DD') in the present work was projected to build up Corte 6 (see Fig. 2 for location).

The amplitude of the Bouguer anomaly ranges from c. -123 to c. $-104 \mathrm{mGal}$. The pattern of the anomaly shows four lineations of relative maxima trending NW-SE with amplitudes ranging between -109 to $-105,-114$ to $-109,-117$ to
-115 and -115 to -112 , respectively (labelled Max1 to Max4, black lines in Fig. 5a). These relative maxima mainly coincide with outcrops of Cretaceous and Jurassic material, two of them located over the Zafra de Záncara anticline, and one on 
Table 1 Root mean square (RMS) of the measures (X and $\mathrm{Y}$ are the horizontal coordinates, $\mathrm{Z}$ is the elevation)

\begin{tabular}{lllll}
\hline & $X(\mathrm{~m})$ & $Y(\mathrm{~m})$ & $Z(\mathrm{~m})$ & Gravity (mGal) \\
\hline RMS & 0.36 & 0.38 & 0.09 & 0.08 \\
\hline
\end{tabular}

the La Rambla anticline. A couple of prominent and roundshaped minima are also observed, one towards the NW, with amplitude of -121 to $-119 \mathrm{mGal}$ and another one at the NE end of the study area, with amplitude of -121 to $-123 \mathrm{mGal}$ (labelled Min1 and Min2 in Fig. 5a).

Because the target structures are in the uppermost part of the crust, modelling requires removing from the Bouguer anomaly a regional field of long wavelength component generated in the deeper crust in order to obtain a residual field that reflects the shallow structures. After several tests to calculate an adequate regional-residual separation, the residual Bouguer anomaly used in this work was obtained subtracting from the Bouguer anomaly a regional field (Fig. 5 b) calculated using the Zeng method (Zeng, 1989). Zeng's method uses a polynomial surface adjust, but the degree of the polynomial is based on upward continuation. When we upward continue the Bouguer anomalies, we suppress the contribution of the shallow source anomalies while the anomalies of deeper bodies remain unchanged. When the height of the upward continuation is large enough, the short wavelength anomalies from shallow bodies are practically zero. It is assumed (Zeng, 1989) that the regional Bouguer anomaly is the polynomial surface which fits that particular upward continued anomaly. The advantage of this method is that allow getting the regional Bouguer anomaly in an objective and repeatable way. After upward continuing the Bouguer anomaly every $500 \mathrm{~m}$ up to $5000 \mathrm{~m}$, we have chosen an upward continuation at $4500 \mathrm{~m}$ and the degree of the polynomial that adjust this upward continuation is 3. This residual (Fig. 5c) is the gravity data used as observed gravity anomaly in the inversion.

The residual Bouguer (Fig. 5c) has a range between -2.5 and $4.5 \mathrm{mGal}$ and depicts more clearly the four main structural axis of NW-SE direction that are also observed in the Bouguer anomaly. These relative maxima have amplitudes ranging from 0 to $4.5 \mathrm{mGal}$, with the maximum values occurring over the axis of the anticlines. The two maxima over the Zafra de Záncara anticline are joined at their northern end. Between the Zafra de Záncara and La Rambla anticlines, a relative lineament of gravity minima crosses the area from NW to SE (labelled MinL2 in Fig. 5c). Another relative lineament of gravity minima (labelled MinL1 on Fig. 5c) is located between the relative maxima on La Rambla and the relative maxima on top of the other anticline at the SW. The amplitude of the relative lows range from -2.5 to $0.5 \mathrm{mGal}$ and can be related to the thick Cenozoic sediments deposited between the anticlines (Fig. 5c).

\section{Petrophysiealdata}

Petrophysical properties are a fundamental constraint to interpret the potential field data and minimize the number of possible solutions during the modelling process. Density was determined analysing the data coming from three different sources:

1. Twenty-one samples collected from the main geological formations that are considered of interest to be modelled (Fig. 5a). The samples have been analysed at the IGME laboratory to obtain its density. The measurements have been made on hammer-cut samples of $0.3-0.6 \mathrm{~kg}$, by weighting them in air and water (Archimedes principle). Sensitivity of the method is about $0.01 \mathrm{~g} / \mathrm{cm}^{3}$ and precision is on the order of $0.02 \mathrm{~g} / \mathrm{cm}^{3}$;

2. lithological information from El Hito-1 drillhole (Lanaja y Navarro, 1987) and

3. petrophysical data for the same formations found in the literature (e.g. Pueyo et al. 2015).

After evaluating the petrophysical information, the densities used in the modelling are, in $\mathrm{g} / \mathrm{cm}^{3}$ (Fig. 6): 2.28 for the Neogene-Qua-ternary; 2.38 for the Paleogene; 2.6 for the Upper Cretaceous, 2.55 for the Lower-Middle Cretaceous, 2.65 for the Middle Jurassic, Lower Jurassic 2 and Lower Jurassic $1 ; 2.5$ for the Keuper; 2.56 for the Buntsandstein-Muschelkalk and 2.75 for the Paleozoic basement.

\section{D-Gravity modelling: Forward modelling and-stochastic inversion}

In this work, we have carried out the modelling using 3D GeoModeller software from Intrepid Geophysics (e.g. Guillen et al. 2008; Gibson et al. 2013) and following four steps:

1. Defining the stratigraphic pile.

In our model, the stratigraphic pile (Fig. 6) defines the chronology of the stratigraphic sequence making possible to manage the relationship between the geological formations in the computation of the 3D model and through the process of inversion.

As depicted in Fig. 6, the model is made of 10 layers: Paleozoic basement; Buntsandstein-Muschelkalk; Keuper; Lower and Middle Jurassic; Lower-Middle and Up- 

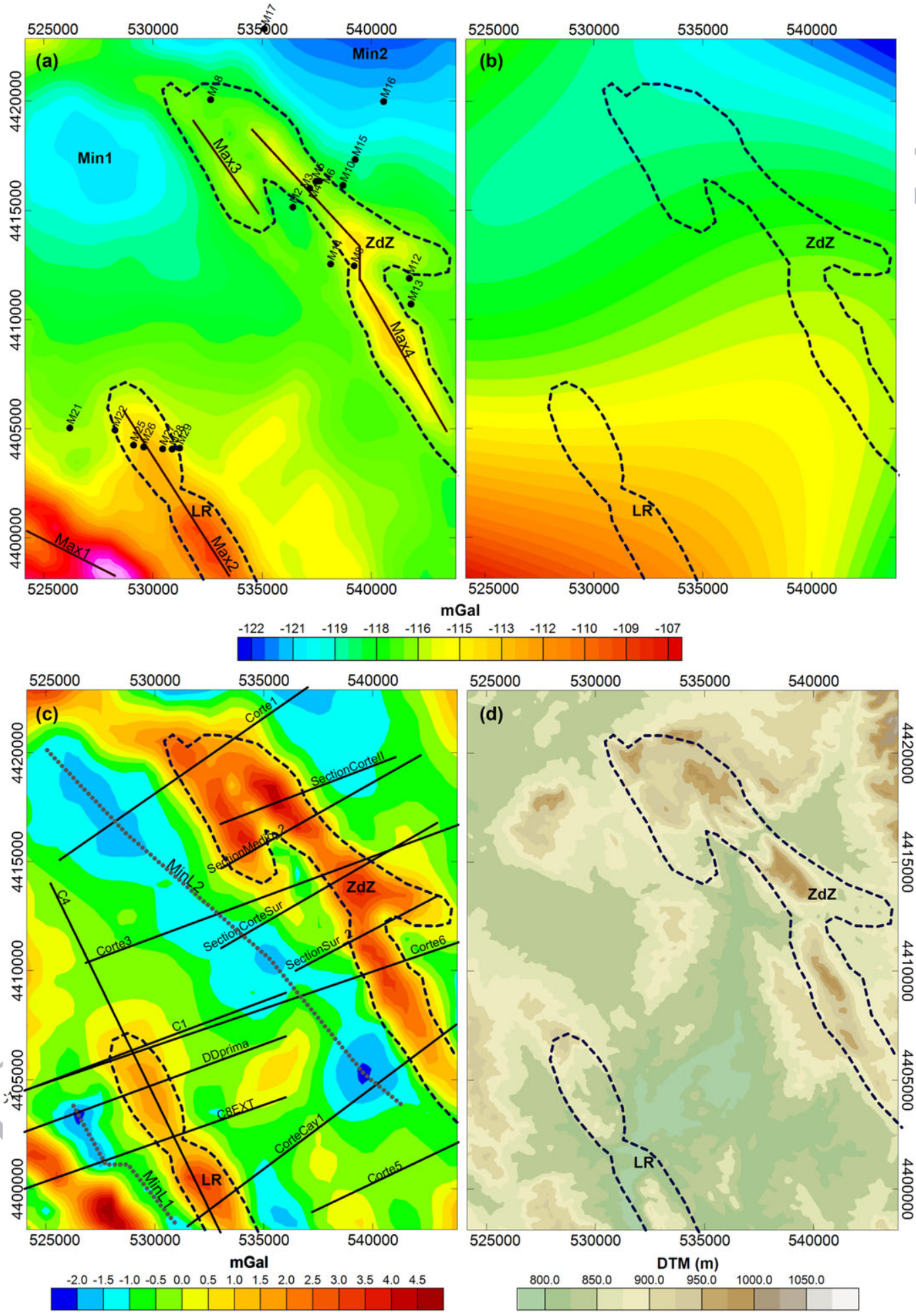

Figure 5 (a) Bouguer anomaly with the lineaments mentioned on the text and the location of the petrophysical samples on top; see the text for explanation of labels Max1, Max2, Max3, Max4 and Min1, Min2. (b) Regional Bouguer anomaly. (c) Residual Bouguer anomaly with the location of the cross sections used in the 3D model and the lineations of the two minimum not seen on the Bouguer anomaly, MinL1 and MinL2 (see the text for explanation). (d) $100 \mathrm{~m}$ Digital Terrain Model used for the topographic correction and the inversion. The four maps show the outline of the geological outcrops of the anticlines (discontinuous dark blue line). LR: La Rambla anticline; ZdZ: Zafra de Záncara anticline. 


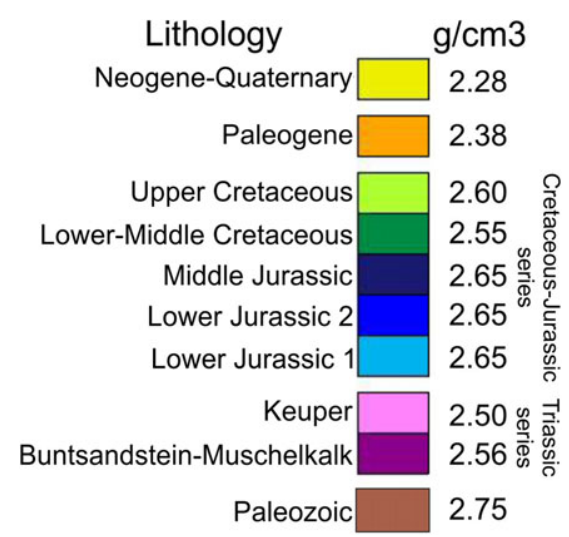

Figure 6 Stratigraphic pile with the densities used in the modelling.

per Cretaceous; Paleogene and Neogene-Quaternary. Some of the formations have been grouped into series: The Triassic series (Buntsandstein-Muschelkalk and Keuper) that supposedly were not affected by the alpine orogeny and the Cretaceous-Jurassic series that were affected and deformed as we see today.

Note that although the three Jurassic layers have the same density and cannot be distinguished in terms of gravity modelling, we have left them separately to be consistent with the geological cross sections that come from the ALGECO2 Atlas (IGME 2009) and we have used these cross sections to build up the 3D model.

2. Generating the initial geological model.

The structural model is build up in a volume that has the same horizontal dimensions as the gravity data, $20 \mathrm{~km} \times$ $25 \mathrm{~km}$, the top is located at the topographic surface (the $100 \mathrm{~m}$ digital elevation model; Fig. 5d) and the bottom at a depth of $-3500 \mathrm{~m}$, which includes the upper part of the Paleozoic basement.

The model has been created from a $100-\mathrm{m}$ grid Digital Elevation Model, geological information from the El Hito-1 borehole (Lanaja and Navarro, 1987), the surface geology from the 1:50,000 National Geological Map (MAGNA) series and 12 geological cross sections that image the main geological structures (see Fig. 2 and 5c for location). The cross sections are based on IGME (2009), Biete (2010) and Biete, Roca and Hernaiz-Huerta (2012), and the reinterpretation of seismic lines DD' and C8ext specifically reworked for this work. All cross sections but $\mathrm{C} 4$, which has a roughly N-S direction, run in SW-NE direction, perpendicular to the geological strike. The lithologies and faults from the cross sections were digitized in GeoModeller and the network of faults affecting the different formations together with the relation- ships between them have also been integrated in the model. The digitized cross sections within GeoModeller together with the surface geology, with the constrains of the topography and the information from the El Hito-1 borehole, are interpolated and extrapolated using co-kriging, assuming that the contact data for each interface lie on a iso-potential surface, and the orientation vectors are orthogonal to a local tangential plane to the potential field (McInerney et al. 2005). In this way, the relevant data that have to be taken into account in the generation of the $3 \mathrm{D}$ surface can be located above or below the geologic contact surface we want to generate.

3. Refining the model by means of forward gravimetric modelling.

Once generated the first 3D model, the cross sections were revised to account for possible inconsistencies and, in some cases, reinterpreted and improved by means of Geomodeler's two-dimensional forward gravity modelling tool. An additional cross section, namely CorteCay1, was built up afterwards based on the surface geological data in order to constraint the section of the model between section C8EXT and Corte 5.

To ensure the convergence in the inversion process, it is best to start off with a model whose gravimetric response has a similar pattern than the observed anomaly. For that reason, we have refined the model through forward calculation: we have computed the gravimetric response of the 3D model and compared with the observed residual gravity anomalies.

This is an iterative process that starts with computing the forward gravity anomaly then reviewing the results and modifying the model by making changes in the cross sections and then repeating the forward calculation. This process will continue until the calculated anomaly pattern resembles that of the observed anomaly. In this way, we also ensure that the results of the inversion will honour not only the gravimetric observations but also the geological inputs. A thorough description of the modelling process can be found in Gillen et al. (2004, 2008). In Fig. 7(a), we show the calculated residual gravity anomalies prior inversion (i.e. the calculated residual anomalies from forward modelling). The misfits prior inversion (observed minus calculated residual gravity anomaly from forward modelling) are shown in Fig. 7(c).

To make the calculations, each lithology of the $3 \mathrm{D}$ volume is discretized in geological 3D cells (voxels). Taking into account the spatial distribution of the gravity data and the resolution of the petrophysical data, the geological model has been discretized in cells of $250 \mathrm{~m} \times 250 \mathrm{~m} \times 25 \mathrm{~m}$. Each cell has a density value according to its lithology. 

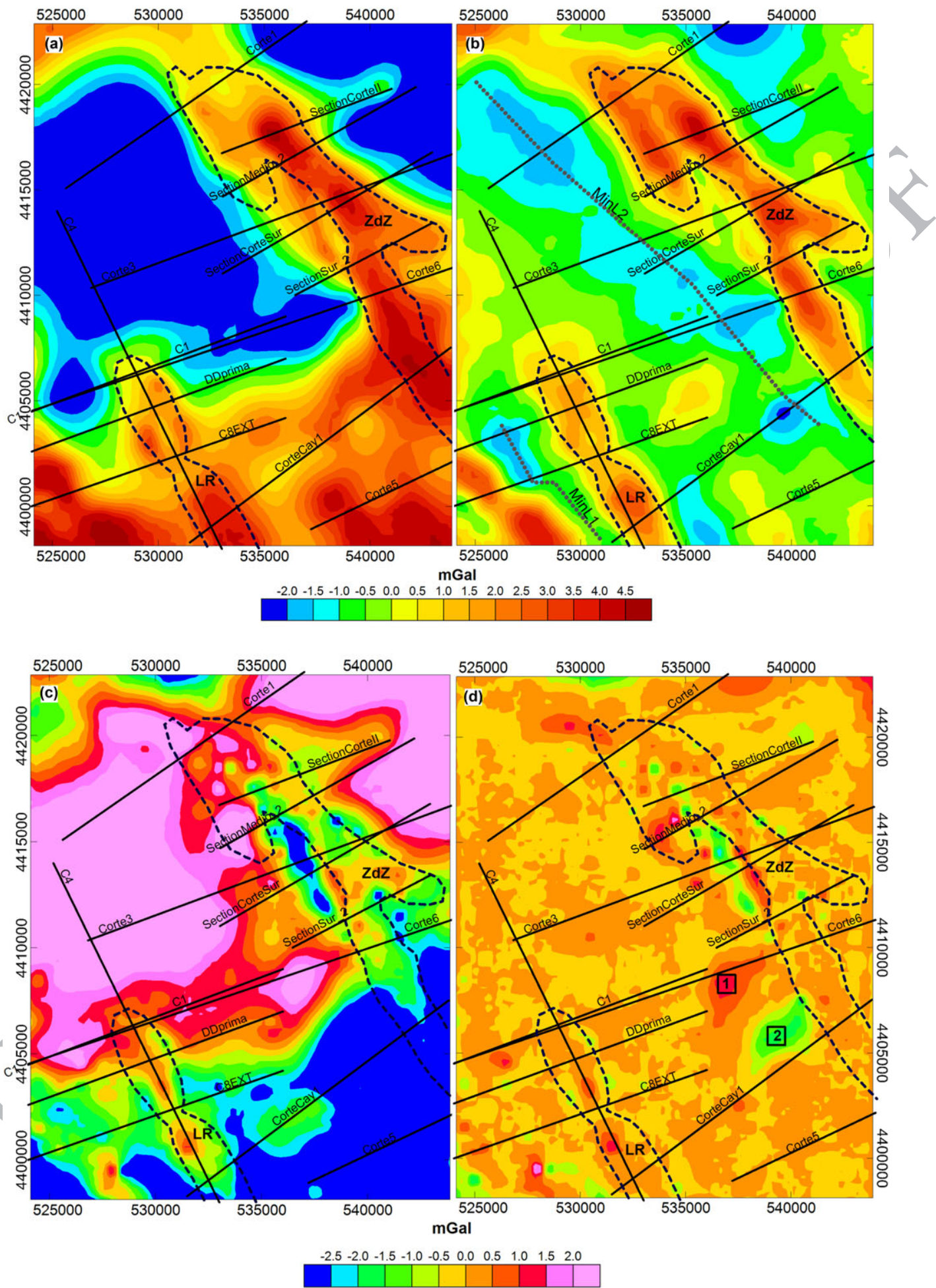

Figure 7 (a) Calculated residual gravity anomaly prior inversion. (b) Calculated residual gravity anomaly after inversion with the liniations of the two minimum seen on the residual Bouguer anomaly (Fig. 5C) labelled MinL1 and MinL2 (see the text for explanation). (c) Misfits (observed minus calculated residual gravity anomaly) prior inversion. (d) Misfits (observed minus calculated residual gravity anomaly) after inversion. The four figures show the location of the cross sections used in the $3 \mathrm{D}$ model and the outline of the geological outcrops of the anticlines (discontinuous dark blue line). 

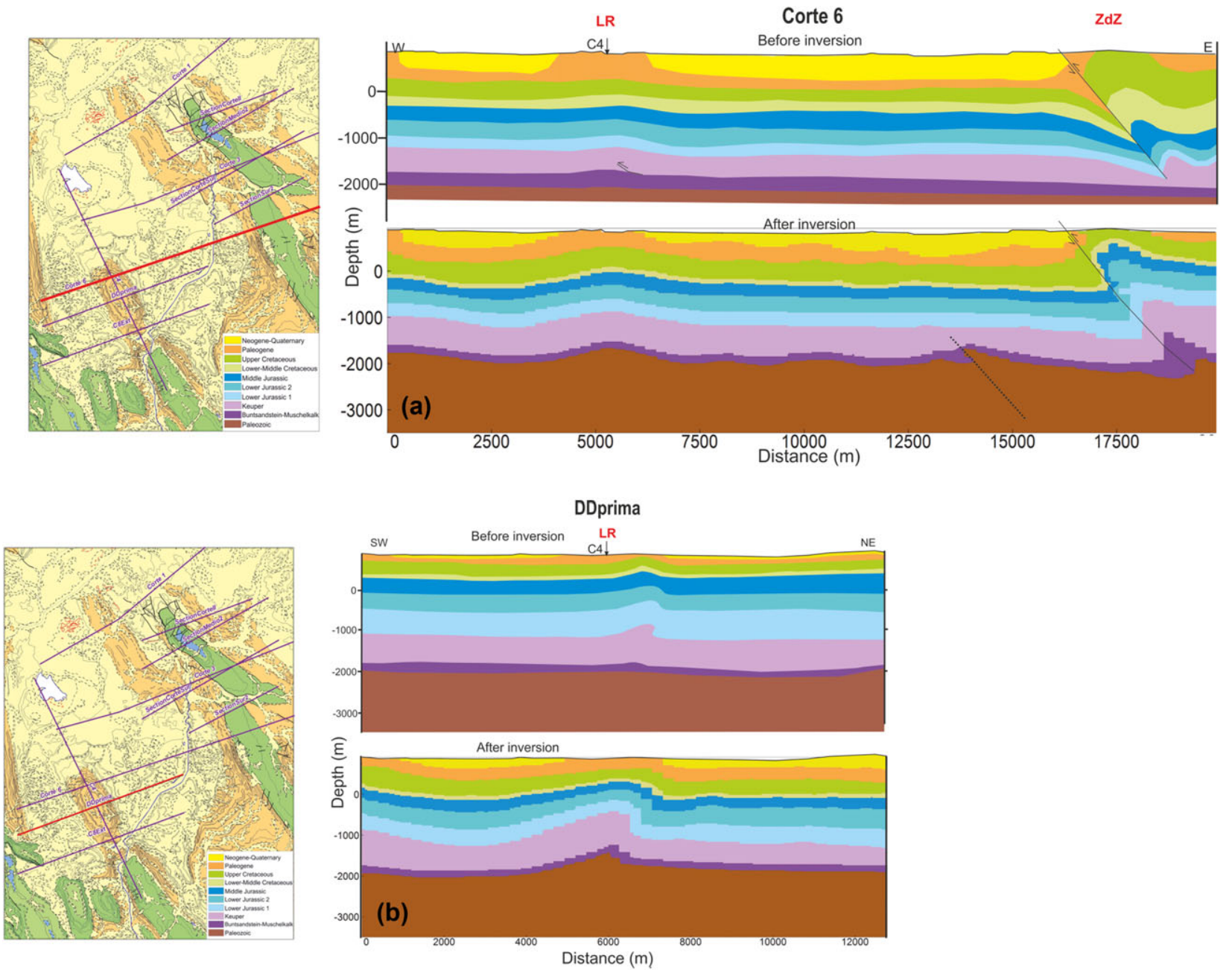

Figure 8 Results of the inversion along cross section Corte 6 and DDprima (a and b respectively). The cross sections before the inversion are also included in the figure for comparison. LR and ZdZ show the location of the anticlines. The location map show the cross sections used in the $3 \mathrm{D}$ modelling. The sections presented in this figure are depicted in red.

\section{Performing the gravimetric inversion.}

GeoModeller inversion uses the same model discretization as in the forward modelling. The calculations of the gravimetric inversion are based on the Monte Carlo Markov Chain method (Tarantola, 2005) that consists of minimizing the gravimetric misfits (difference between observed and calculates gravity anomalies) by changing the lithological boundaries, the density or both parameters. For this inversion, we have set the geological constraints to allow changes in the lithological boundaries with an uncertainty of $25 \%$ and leaving the densities to change within a standard deviation of $0.02 \mathrm{~g} / \mathrm{cm}^{3}$, which corresponds to the uncertainty assigned to the measurements. The probability of property change is set to $50 \%$. Consequently, the inversion process modifies both geometry and density of the differ- ent lithologies within the uncertainty parameters. The edge effects are avoided by expanding the geological model and by reflecting and rotating the modelled geology itself across the edges and corners of the model. The inversion has run for $50 \times 10^{6}$ iterations, and at the end of the inversion the root mean square of the misfits (difference between observed and calculated residual Bouguer anomaly) has been $0.32 \mathrm{mGal}$.

\section{RESULTS}

In general terms, the pattern of the calculated anomaly after the inversion (Fig. 7b) is quite similar to the one of the observed anomaly (Fig. 5c). In the areas that are well constrained by the cross sections, the misfits show values between -0.5 and $+0.5 \mathrm{mGal}$ except for small and localized misfits of higher 

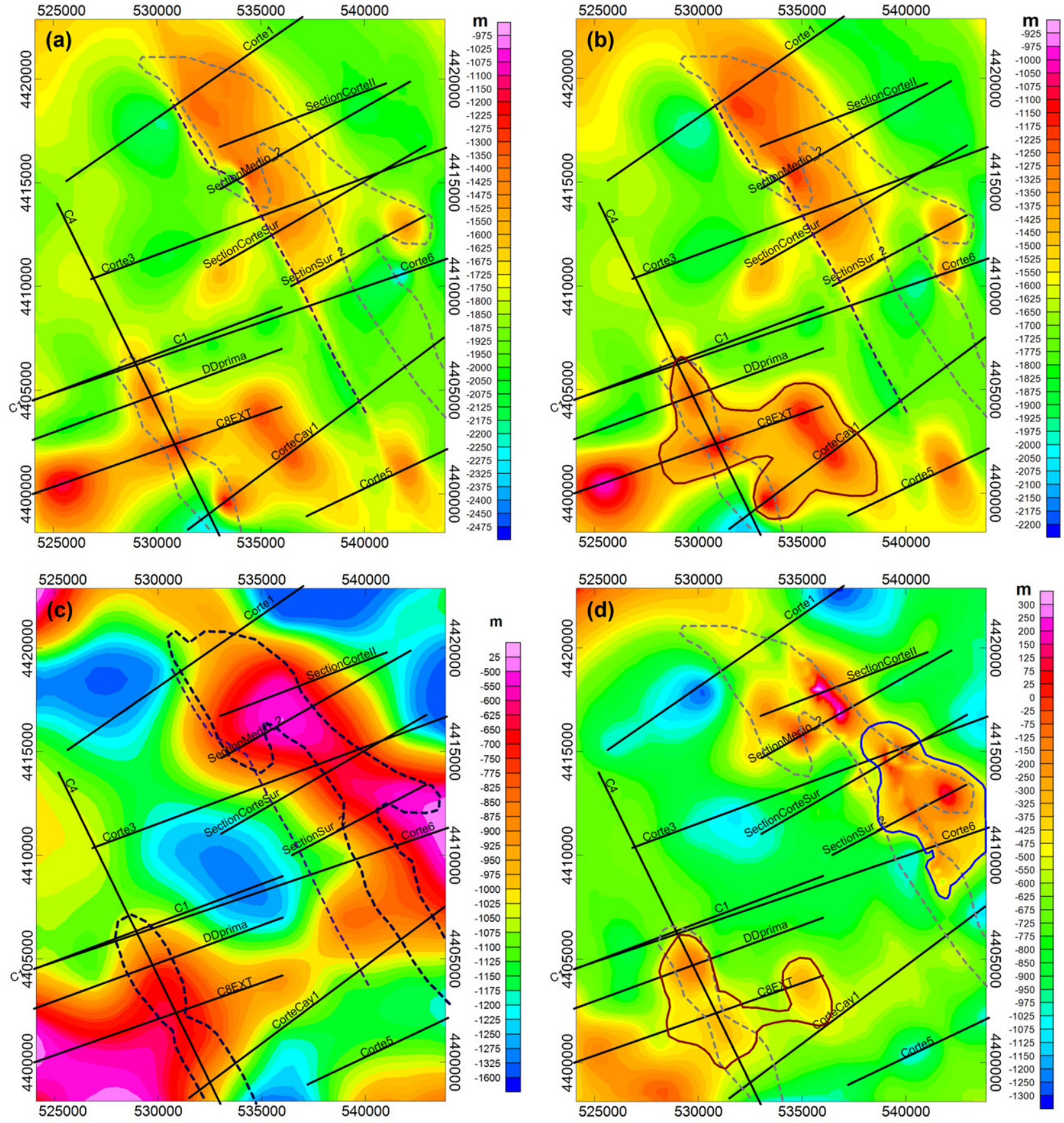

Figure 9 (a) Top of the basement obtained from the inversion. The figure shows the location of the cross sections used in the 3D model and the outline of the geological outcrops of the anticlines (discontinuous dark blue line). In purple dashed line: basement fault that crosscut the Buntsandstein-Muschelkalk layer. (b) Top of the Buntsandstein-Muschelkalk obtained from the inversion. The figure shows the location of the cross sections used in the 3D model and the outline of the geological outcrops of the anticlines (discontinuous dark blue line) as well as the outline of the La Rambla and Zafra de Záncara new possible structural closure in maroon. In purple dashed line: basement fault that crosscut the Buntsandstein-Muschelkalk layer. (c) Top of the Keuper obtained from the inversion. The figure shows the location of the cross sections used in the 3D model and the outline of the geological outcrops of the anticlines (discontinuous dark blue line). In purple dashed line: basement fault that crosscut the Buntsandstein-Muschelkalk layer. (d) Top of the Lower Jurassic. The figure shows the location of the cross sections used in the 3D model and the outline of the geological outcrops of the anticlines (discontinuous dark blue line) as well as the outline of the La Rambla and Zafra de Záncara new possible structural closures in maroon and dark blue, respectively. 

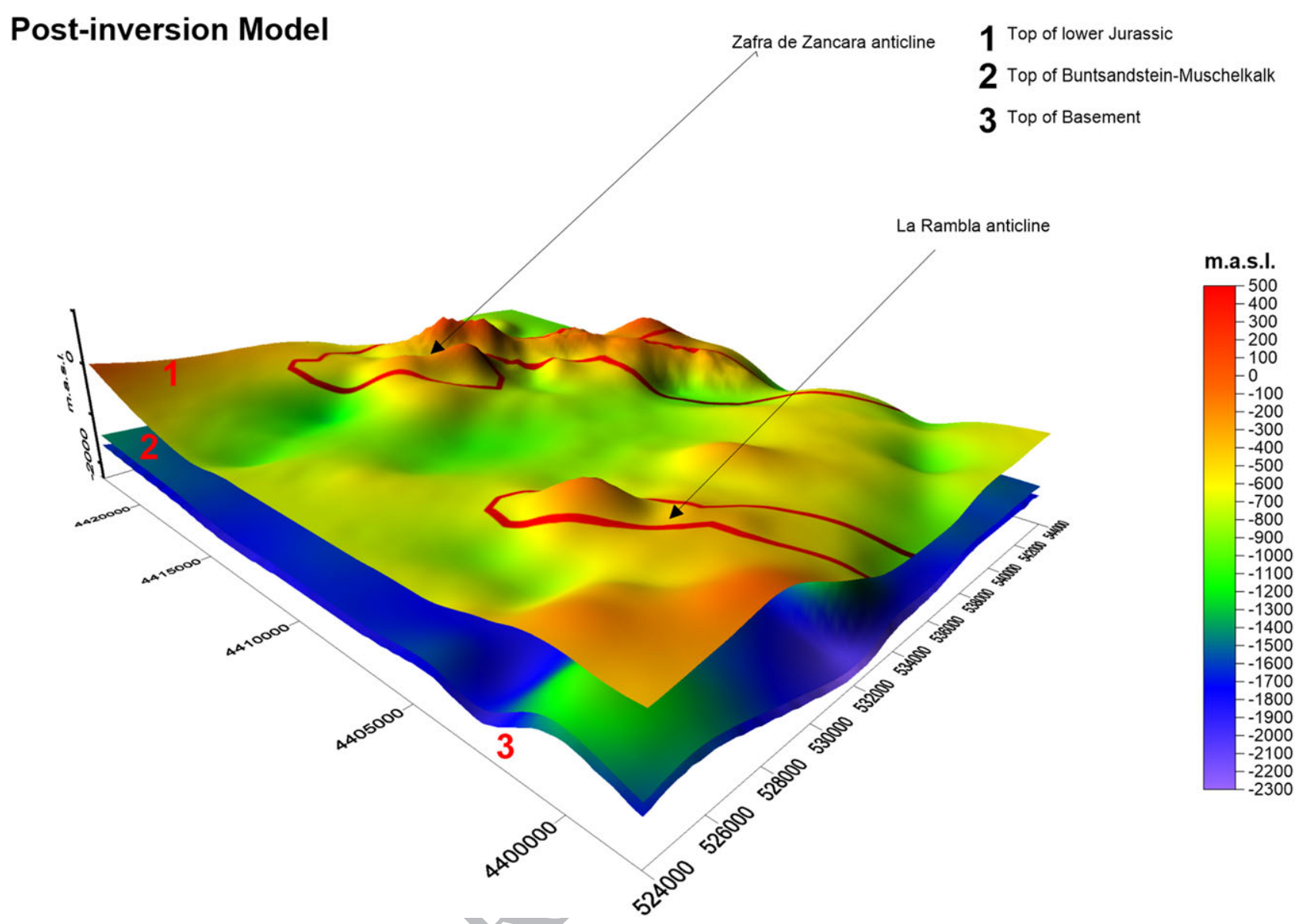

Figure 10 3D model depicting the target layers: Top of the basement (number 3), top of Buntsandstein-Muschelkalk (number 2) and top of Lower Jurassic (number 1). Red line: outhe of the outcrops of the anticlines.

amplitude that are attributed to superficial density inhomogeneities but do not affect the geometry of the targeted layers (Fig. 7d). The most relevant misfits are the two elongated ones with amplitudes ranging between 0 and $1 \mathrm{mGal}$ (labelled as 1 on Fig. $7 d$ ) and between 0 and $-1 \mathrm{mGal}$ (labelled as 2 on Fig. $7 d$ ) placed slightly SW of the Zafra de Záncara anticline. These misfits are located in a place with no constraints but already out of our areas of interest, and, therefore, the uncertainty associated does not affect the evaluation of the possible structural closures.

As a succinct summary of the results, we have chosen Corte 6 and DDprima (Fig. $8 \mathrm{a}$ and b) as the most representative of the differences between the initial and final model. Comparing both cross sections, the results show that in some places the Buntsandstein-Muschelkalk it is slightly thinner than the one from initial model (like in the La Rambla anticline), whereas in other places, its thickness has not changed during the inversion (like in some places in the Zafra de Záncara anticline). It is worth noticing the accumulation of Buntsandstein-Muschelkalk along the westernmost basement fault of Zafra de Zancara, reaching thicknesses that can be of the order of $400 \mathrm{~m}$. According to the results of the inversion, this fault cuts the Buntsandstein-Muschelkalk facies and it also seems to affect the basement. The inversion shows that the basement has some relief of antiformal shape not depicted in the initial cross sections (e.g. Fig. 8a). One of these antiforms seems to be limited by a fault (see also Fig. 8a) that can be interpreted as a reverse fault of as a normal fault that has been inverted because the basement was affected by compression (as already suggested in Biete (2010)). Note that to build up the cross section DDprima presented in this work, we reinterpreted the seismic line of the same name in the area that crosses the La Rambla anticline that overlaps with Corte 4 cross section displayed in Fig. 4. The initial geometry of our Corte 6 that runs parallel to cross section DDprima is based on that profile. 
Comparing the model from ALGECO2 Atlas (IGME 2009) (depicted in Fig. 3a-c) and the model resulting from the inversion (Fig. 9a-c), we can observe several differences:

1. The basement isolines of Fig. 9(a) show a more complex basement, both with respect to the structure of La Rambla (with a basement elevation not interpreted previously), as well as to the troughs between the structural highs of the area. The results of the inversion show that below the La Rambla anticline, the basement is not as flat as previously interpreted (see Fig. 3a) but folded into smaller anticlinal structures and 50$450 \mathrm{~m}$ deeper than in the initial model, particularly towards the $\mathrm{N}$ of the anticline. In the southernmost part, with lesser constraints, the anticline is more than $1000 \mathrm{~m}$ deeper.

In the Zafra de Záncara anticline, the basement folds appear better defined and in the zone between Corte 1 and Corte 6, its depth is up to $225 \mathrm{~m}$ shallower than in the initial model. From the results of the inversion, we suggest that the basement fault affecting not only the basement but also the Buntsandstein-Mushelkalk Fm. can be extended further south for $11 \mathrm{~km}$ (purple dotted line in Fig. 9a and b; black dotted line on Corte 6 in Fig. 8a). However this fault does not seem to affect the Lower Jurassic.

2. In the isolines map of the Buntsandstein-Muschelkalk top (Fig. 9b), the most important changes are in its geometry more than in its thickness: the top of the BuntsandsteinMuschelkalk depicts a more defined anticlinal geometry and it is located a few tens of meters deeper in some areas. The troughs that separate them also appear better defined. The Buntsandstein-Muschelkalk in the La Rambla anticline is slightly thinner than in the initial model (from 25 to $50 \mathrm{~m}$ ) and a few tens of meters shallower whereas in the Zafra de Záncara anticline the thickness has remained almost unchanged except along the westernmost basement fault, where we find accumulations of Buntsandstein-Muschelkalk of about $400 \mathrm{~m}$ (e.g. Corte 6, Fig. 8a).

3. In the La Rambla anticline, changes in the thickness of the Keuper are of the order of tens of meters whereas in Zafra de Záncara are closer to the ones of the initial model (see top of the Keuper in Fig. 9c)

Top of the Lower Jurassic 1 isolines (Fig. 9d) are located approximately between 0 and $-1200 \mathrm{~m}$ (asl). Lower Jurassic 1 is deeper towards the west and shallower towards the east. The most relevant difference in depth lies at the eastern end of Corte 6, where the Lower Jurassic is c. $700 \mathrm{~m}$ shallower. In most of the study area, the Lower Jurassic 1 has approximately the same thickness as in the initial model. One exception is the thickness along section DDprima (Fig. 8b) in the La Rambla anticline, where the results of the inversion show a thinner
Lower Jurassic 1, which is more consistent with its thickness everywhere else in the anticline.

The most relevant changes in the thickness of the Cretaceous, Paleogene and Neogene-Quaternary layers occur in the zone between the anticlines, where these layers are several tens of meters thicker. In Zafra de Záncara and La Rambla anticlines, their thicknesses are closer to the ones in the initial model.

\section{DISCUSSION AND CONCLUSIONS}

Comparing the initial and final model, we observe the following:

In areas with sufficient seismic coverage such as Zafra de Záncara, the structures obtained in both models are quite similar in geometry, although the stochastic inversion process results in a slightly shallower anticlinal geometry (between 50 and $100 \mathrm{~m}$ ). That means, according to the density profile, that the seismic model presents a slight mass deficit, which is corrected in the gravimetric inversion process.

The results of the inversion differ from the interpretation of Múnoz-Martín and De Vicente (1998) that have the view the anticlines detected from the seismic data to the east of the Altomira Range, including Zafra de Záncara and La Rambla, are "pull up" type artifacts from the seismic interpretation due to the increase of the seismic velocities where the sedimentary cover duplicates. Our 3D modelling results show that the anticlinal structures of Zafra de Záncara and La Rambla involve the basement thus indicating that the basement highs interpreted from the seismic reflection data are real structures and not artefacts.

The most relevant differences occur where seismic coverage is scarce or non-existent. In Zafra de Záncara, these differences are located at the SE of the anticline: here the process of stochastic gravimetric inversion suggests the presence of a small closure in the Buntsandstein-Muschelkalk, in an area where there is no seismic coverage. The structure of the Lower Jurassic 1 has only seismic coverage along line C10, so its geometry comes exclusively from the gravimetric inversion. In addition, some of the Zafra de Záncara folds seem to be less affected by the faults than previously thought in the sense that the throw of the faults is, in general, smaller.

In the La Rambla anticline, the lack of the seismic information to constrain the initial model has resulted in greater freedom to modify the geometry of the lithologies so the calculated gravity anomaly would fit the observed anomaly. The most relevant differences are a more complex structure especially of the basement that appears more folded and deeper 
compared with the almost flat basement in the initial model. Also, the Buntsandstein-Muschelkalk is slightly thinner.

- The possibility of the southern continuation of a fault affecting the basement and the Buntsandstein-Muschelkalk, in previous models though to be affecting only the northern part of Zafra de Záncara westernmost border, have been deduced from the inversion (purple dotted line in Fig. 9a and $b)$.

Concerning to the study of possible structural closures that might be used as $\mathrm{CO}_{2}$ reservoirs, the gravimetric inversion has helped to define the geometry of possible structural closures particularly in places where the information from the seismic data were inconclusive.

- In the top of the Buntsa-ndstein-Muschelkalk (Fig. 9b), the possible candidates to be a $\mathrm{CO}_{2}$ structural closures are delimited by the $-1500 \mathrm{~m}$ isoline that corresponds to an approximate depth of c. $2100 \mathrm{~m}$, measuring from the topography. The maximum thickness of the structural closures is c. $200 \mathrm{~m}$, and they are sealed by the evaporitic material of Keuper, with thicknesses of more than $500 \mathrm{~m}$. The structures in the Zafra de Záncara anticline were already defined in the ALGECO2 project. Here our results that show better defined geometries are consistent with that of the ALGECO2. In the La Rambla anticline, it is possible to delineate up to four closed structural highs that have been deduced from the gravity inversion only.

- In the top of Lower Jurassic map (Fig. 9d), two new possible structural closures are depicted, one in the Zafra anticline, with an average thickness of $250-300 \mathrm{~m}$, reaching c. $400 \mathrm{~m}$ in some places and another one beneath La Rambla with thickness ranging between 200 and $400 \mathrm{~m}$. These potential structural closures are delimited by the $500 \mathrm{~m}$ isoline that corresponds to depths beneath the topography of c. $800 \mathrm{~m}$ in La Rambla and $1000 \mathrm{~m}$ in the Zafra de Záncara anticlines. The sedimentary cover acts as a seal, having more than $1200 \mathrm{~m}$ in thickness.

Nonetheless, more studies (porosity, etc.) are needed to evaluate the storage capacity in order to decide whether the use of these plausible structural closures is feasible.

Our 3D model (Fig. 10) improves the geological knowledge of the ALGECO2 model in three ways:

1. It depicts the geometry of all the layers defined in the stratigraphic pile, unlike the ALGECO2 model where only the top of the basement, top of Buntsandstein and top of Keuper was obtained.

2. The surfaces of the 3D model obtained from the inversion honour all the observables (gravity, seismic, surface geology and petrophysical data) with a horizontal uncertainty of $125 \mathrm{~m}$ and an uncertainty in depth of $12.5 \mathrm{~m}$, whereas the surfaces from ALGECO2 (IGME 2009) where obtained by manually interpolating the cross sections based on seismic interpretation and surface geology, implementing geological constraints. Therefore, we believe that the geological surfaces obtained from the gravity inversion have more definition and better resolution than the ones previously published.

3. Our characterization of La Rambla anticline allows us to take it into account as possible $\mathrm{CO}_{2}$ storage site since four closed structures in the Buntsandstein-Muschelkalk and one in the Lower Jurassic 1 have been identified. Moreover, one more closed structure in the Lower Jurassic 1 in the Zafra de Záncara anticline has been recognized. These structures were not singled out during the ALGECO2 project.

\section{ACKNOWLEDGEMENTS}

This study has been supported by the Instituto para la Reestructuración de la Minería del Carbón y el Desarrollo Alternativo de las Comarcas Mineras, Ministry of Energy and Industry, Spain. We thank José Luís García-Lobón and Manuel Bernat for their help in the first stages of the modelling. We also thank Serguei Goussev and Pavol Zahorec for their constructive comments and suggestions that have helped to improve this manuscript.

\section{OR CID}

C. Ayala (D) https://orcid.org/0000-0001-8457-8253

\section{REFERENCES}

Álvaro M., Capote R. and Vegas R. 1979. Un modelo de evolución geotectónica para la Cadena Celtibérica. Acta Geológica Hispánica $14,172-177$.

Biete C. 2010. La estructura alpina del basamento hercínico en la zona del Hito (sector meridional de la Cuenca de Loranca) y su influencia en la deformación contractiva de los materiales suprayacentes: Caracterización tridimensional de la estructura. Tesis de Máster, Universidad de Barcelona, Barcelona, Spain, 17 pp.

Biete C., Roca E. and Hernaiz-Huerta P.P. 2012. The Alpine structure of the basement beneath the southern Loranca Basin and its influence in the thinskinned contractional deformation of the overlying Mesozoic and Cenozoic cover. Geo-Temas, 13, 173.

Díaz-Molina M., Arribas J., Gómez J.J and Tortosa A. 1995. Geological modelling of a reservoir analogue: Cenozoic meander belts, Loranca Basin, Spain. Petroleum Geoscience 1, 43-48.

Gibson H., Sumpton J., Fitzgerald D. and Seikel R. 2013. 3D modelling of geology and gravity data: summary workflows for minerals exploration. East Asia: Geology, Exploration Technologies and Mines, Bali, 2013. 
Gómez J.J., Díaz Molina M. and Lendínez A. 1996. Tectonosedimentary analysis of the Loranca Basin (Upper Oligocene-Miocene, central Spain): a 'non sequenced' foreland basin. In: Tertiary basins of Spain (eds. P.F. Friend and C.J. Dabrio), pp. 285-294. Cambridge University Press, Cambridge.

Guimerà J. and Álvaro M. 1990. Structure et evolution de la compression alpine dans la Chaîne Iberique et Chaîne Cotiere Catalane. Bulletin de la Société géologique de France 8 (VI), 339-348.

Guillen A., Courrioux G., Calcagno P., Lane R., Lees T. and McInerey P. 2004. Constrained gravity 3D litho-inversion applied to Broken Hill. SEG 17th Geophysical Conference and Exhibition, Sydney.

Guillen A., Calcagno Ph., Courrioux G., Joly A., Ledru P. 2008. Geological modelling from field data and geological knowledge, Part II - Modelling validation using gravity and mag-netic data inversion. Physics of the Earth and Planetary Interiors 171, 158-169. http://doi.org/10.1016/j.pepi.2008.06.014.

Hammer S. 1939. Terrain corrections for gravimeter stations. Geophysics 4, 184-194.

IGME. 2009. Plan de selección y caracterización de áreas y estructuras favorables para el almacenamiento geológico de $\mathrm{CO}_{2}$ en España. SID IGME database docs $n^{\circ} 64.044$ to 64.055 .

Instituto Español de Normalización (IRANOR). 1985. UNE Norm 22-611-85. 6 pp.

ITGE, 1990. Documentos sobre la Geología del Subsuelo de España. Tomo III (Madrid - Depresión Intermedia). ITGE, Madrid.

Lanaja J.M. y Navarro A. 1987. Contribución de la exploración petrolifera al conocimiento de la Geología de España, 465 pp. Instituto Geológico y Minero de España, Madrid.

McInerney P., Guillen A., Courrioux G., Calcagno P. and Lees T. Building 3D geological models directly from the data? A new approach applied to Broken Hill, Australia. 2005. U. S. Geological Survey Open-File Report 2005-1428.

Muñoz-Martín A. and De Vicente G. 1998. Cuantificación del acortamiento alpino y estructura en profundidad del extremo sur-occidental de la Cordillera Ibérica (Sierras de Altomira y Bascuñana). Revista de la Sociedad Geológica de España 11, 39-58.

Nettleton L. L. 1971. Elementary Gravity and Magnetics for Geologists and Seismologists. Society of Exploration Geophysicists, Tulsa, OK.

Piña-Varas P., Ledo J., Queralt P., Roca E., García-Lobón J. L., Ibarra P. and Biete C. 2013. Two-dimensional magnetotelluric characterization of the El Hito Anticline (Loranca Basin, Spain), Journal of Applied Geophysics, 95, 121-134. http://doi. org/10.1016/j.jappgeo.2013.06.002.

Pueyo E.L., Izquierdo-Llavall E., Rodríguez-Pintó A., Rey-Moral C., Oliva-Urcia B., Casas A.M., et al . 2015. Petrophysical properties in the Iberian Range and surrounding areas (NE Spain): 1density. Journal of Maps, 12, 836-844. https://doi.org/10.1080/ 17445647.2015.1084545

Querol R. 1989. Geología del subsuelo de la Cuenca del Tajo, 48 pp. Escuela Técnica Superior de Ingenieros de Minas de Madrid, Madrid.

Tarantola A. 2005. Inverse Problem Theory and Model Parameter Estimation, 342 pp. SIAM. Philadelphia, PA.

Valcárcel-Rodríguez M. 2015. Reconstrucción y restitución 3D del anticlinal de Puerta-Pareja y estudio de su evolución deformacional

y cinemática en su contexto regional (cuenca de Loranca y Sierra de Altomira). PhD Thesis, Universitat de Barcelona, Barcelona, Spain, $285 \mathrm{pp}$.

Zeng H. 1989. Estimation of the degree of polynomial fitted to gravity anomalies and its application. Geophysical Prospecting, 37: 959-973. https://doi.org/10.1111/j.1365-2478.1989.tb02242.x 